University of California, Hastings College of the Law UC Hastings Scholarship Repository

Faculty Scholarship

2005

\title{
Contemporary Politics of Wilderness Preservation
}

John D. Leshy

UC Hastings College of the Law, leshyj@uchastings.edu

Follow this and additional works at: http://repository.uchastings.edu/faculty_scholarship

Part of the Natural Resources Law Commons

\section{Recommended Citation}

John D. Leshy, Contemporary Politics of Wilderness Preservation, 25 J. Land Resources \& Envtl. L. 1 (2005).

Available at: http://repository.uchastings.edu/faculty_scholarship/381

This Article is brought to you for free and open access by UC Hastings Scholarship Repository. It has been accepted for inclusion in Faculty Scholarship

by an authorized administrator of UC Hastings Scholarship Repository. For more information, please contact marcusc@uchastings.edu. 


\title{
Faculty Publications \\ UC Hastings College of the Law Library
}

\author{
Author: John D. Leshy \\ Source: $\quad$ Journal of Land, Resources \& Environmental Law \\ Citation: 25 J. Land Resources \& Envtl. L. 1 (2005). \\ Title: $\quad$ Contemporary Politics of Wilderness Preservation
}

Originally published in JOURNAL OF LAND, RESOURCES \& ENVIRONMENTAL LAW. This article is reprinted with permission from JOURNAL OF LAND, RESOURCES \& ENVIRONMENTAL LAW and University of Utah S.J. Quinney College of Law. 


\title{
Contemporary Politics of Wilderness Preservation
}

\author{
John D. Leshy
}

Preserving unroaded wild landscapes in their natural condition by law has a distinctively American character. Led by a passionate citizen's movement, it appeals-in Lincoln's phrase - to the better angels of our nature, looking beyond narrow self-interest to future generations. Preserving wilderness is an idea that has, seemingly paradoxically, lifted our civilization to higher ground. It becomes more urgent as man's influence spreads across the Earth. The wilderness movement's moral center gives it credibility and political strength, and is a basic reason why it has been, by any measure, enormously successful.

The national government owns and manages most of this country's wild land, so it was perhaps inevitable that the wilderness protection movement would flower in the federal bureaucracy. The pioneers were Aldo Leopold and Arthur H. Carhart, around 1920, in the U.S. Forest Service. ${ }^{1}$ Later other civil servants like Bob Marshall in the Department of the Interior joined in. Many forget that the progenitors of the wilderness protection movement were-to use the modern, unfortunately pejorative label-mere "bureaucrats." But of course our government is composed of people who are as capable of great and not-so-great things as the rest of us, and preserving large tracts of wilderness by law stands, at the dawn of the twenty-first century, as one of government's great achievements.

The early advocates preserved wilderness by executive branch decree. This was somewhat fragile, because it could be reversed by future executives. To make protection more permanent, wilderness advocates sought-and in 1964 Congress enacted-the Wilderness Act (the Act). ${ }^{2}$ It created the National Wilderness Preservation System (NWPS) and designated charter member areas across more than nine million acres of national forest lands. The Act recognized that the NWPS would grow over time, but it specified that additions could only be made by future acts of Congress. ${ }^{3}$

While this subjected future permanent wilderness designation to the political process, politics has always played a part in formally protecting wilderness by law. Indeed, one reason the leadership of the Forest Service decided in the 1920s to endorse the Leopold/Carhart idea of putting wild land off limits to development

* John D. Leshy is the Harry D. Sunderland Distinguished Professor of Law, University of California Hastings College of the Law. This essay grew out of remarks delivered at the Wallace Stegner Center Symposium on Wilderness: Preserving Nature in a Political World held at the University of Utah, S.J. Quinney College of Law, April 2004. In keeping with the essay format, the author has kept footnotes to a minimum. The author appreciates the able research assistance provided by Doug Obegi, of the Hastings College of Law class of 2006, who also prepared the graph.

${ }^{1}$ See generally RODERICK NASH, WILDERNESS AND THE AMERICAN MIND 184-87, 203-06 (4th ed. 2001).

${ }^{2} 16$ U.S.C. $\$ \S 1131-36(2000)$.

${ }^{3}$ Id. $\$ 1131(\mathrm{a})$. 
was to show the upstart National Park Service, then only eight years old, that the Forest Service could manage large landscapes for preservation and primitive recreation too. ${ }^{4}$

Securing enactment of the Wilderness Act was not easy, for a kind of moral passion also motivated its opponents. This countervailing sentiment was the legacy of the European advance across the American landscape and viewed wilderness as an obstacle to be conquered by putting man's imprint on the landscape. Opinions of the U.S. Supreme Court 131 years apart nicely bracketed the competing theologies: In 1836, the Court found cause for celebration that a tract of land which a few years earlier was "but of little value, in a wilderness, is now the site of large and flourishing cities." In 1967, the Court turned this rhetoric upside down, speaking favorably of the "public interest in preserving . . wilderness areas." $\mathrm{It}$ was practically inevitable that the Wilderness Act reflected an accommodation between these cultural worldviews. Wilderness opponents compromised, in both the original Act and in subsequent legislation designating more wilderness, for a variety of important and still salient reasons: (a) many came, with varying degrees of reluctance, to recognize that the highest and best use of many of these lands is wilderness - that it is not economically realistic to think of such landscapes as anything else; (b) many came to see that they shared some of the goals of wilderness advocates - to preserve wildlife habitat and other features that enhance the quality of rural life; (c) many came to recognize the value of ending the sometimes rancorous debate and achieving a measure of certainty and stability; (d) compromise gained wilderness opponents some measure of control over drawing the boundaries of designated areas, and setting the terms of their management, to minimize constraint on uses important to local communities; and finally, (e) recognition has grown that designating wilderness does not doom surrounding communities to economic oblivion by locking up valuable resources, but instead has tended to have a positive economic impact-strongly positive at best, and merely neutral at worst—on local economic health. ${ }^{7}$

But proponents of wilderness protection also had to yield ground. The Act's poetic rhetoric - defining wilderness as "untrammeled by man ... retaining ... primeval character and influence" compromises which went way beyond garden-variety protections for "vested" or "valid existing rights" that appear in most legislation. The most important of these included: (a) giving the President open-ended authority to approve reservoirs and other water works, power projects, transmission lines, and "other facilities needed in the public interest, including the road construction and maintenance essential to

\footnotetext{
${ }^{4}$ See NASH, supra note 1 , at 184-85.

${ }^{5}$ Voorhees v. Bank of the United States, 35 U.S. (10 Pet.) 449, 473 (1836).

${ }^{6}$ Udall v. Fed. Power Comm'n, 387 U.S. 428, 450 (1967).

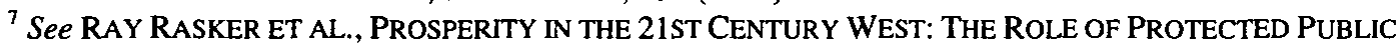
LANDS, (2004).

${ }^{8} 16$ U.S.C. $\S 1131$ (c) $(2000)$.
} 
development and use thereof" in national forest wilderness areas'; (b) giving hardrock mining companies a twenty-year window to stake new mining claimsany of which could turn into open pit mines-in national forest wilderness areas ${ }^{10}$; (c) giving the Secretary of the Interior a twenty-year window to issue new oil and gas, coal, and other kinds of mineral leases in national forest wilderness areas ${ }^{11}$; and (d) allowing livestock grazing to continue where already established, subject to reasonable regulation. ${ }^{12}$

Plainly these provisions had the potential to eviscerate the national forest wilderness areas designated by the original Act, as well as future designations. They must have been difficult for wilderness advocates to swallow. But they were necessary to get the legislation through the congressional gauntlet, and so wilderness advocates went along. The gamble turned out well. Although grazing has continued, there have been no water projects and almost no mineral development authorized in wilderness areas. ${ }^{13}$

$$
* * *
$$

In the more than four score years since the first few thousand acres were protected by bureaucratic memorandum, the wilderness movement has been propelled along by that mixture of idealism and pragmatism which characterizes many successful social movements. Its achievement is plain: Today the National Wilderness Preservation System encompasses more than 600 units and upwards of 100 million acres-an area larger than California, about three percent of the total land area in the country. Most of the nearly twelve-fold expansion in acreage since 1964 has come in the form of multi-million-acre wilderness bills enacted between the mid-1970s and the mid-1980s. Congress has tended to package wilderness legislation by land management agency, and often state-by-state; for example, a BLM wilderness bill in Arizona or a national forest wilderness bill in Utah. In a class by itself was the monumental Alaska National Interest Lands Conservation Act of 1980 (ANILCA), which alone designated more than fifty million acres of wilderness among all four big federal land management agencies: the National Park Service (NPS), the U.S. Fish and Wildlife Service (FWS), the U.S. Forest Service (Forest Service), and the Bureau of Land Management (BLM). ${ }^{14}$ All the wilderness designated in the original Wilderness Act was in national forests, but Congress also acknowledged that some lands in the national park and wildlife

\footnotetext{
${ }^{9}$ Id. § 1133(d)(4).

${ }^{10} \mathrm{Id}$.

"Id. §1133(d)(3).

${ }^{12} I d$. $\S 1133(\mathrm{~d})(4)$.

${ }^{13}$ See George Cameron Coggins, et al., Federal Public Land and Resources LaW 1113-14, 1125 (5th ed. 2002).

${ }_{14}$ Id. at 1129-30, 1136; see, e.g. Ross W. Gorte, Wilderness: Overview \& Statistics, at http://www.ncseonline.org/nle/crsreports/ natural/nrgen-5.cfm (last visited Nov. 10, 2004); see generally DouG SCOTT, THE ENDURING WILDERNESS: PROTECTING OUR NATURAL HERITAGE THROUGH THE WILDERNESS ACT (2004).
} 
refuge systems could qualify for wilderness designation. ${ }^{15}$ In 1976 Congress formally brought BLM into the wilderness process in the Federal Land Policy and Management Act (FLPMA). ${ }^{16}$

Although much progress has been made, there is still much left to do. Estimates vary, but it is fair to say that as much federal land as is already in the system (106 million acres) is, although not now in the system, currently wild enough to qualify for it. While some of this is in national parks and wildlife refuges, Congress has not, since ANILCA, been pressed very hard to designate more park and refuge wilderness. These lands generally face fewer development pressures than federal lands managed by the Forest Service or the BLM, and they involve comparatively fewer acres. The upshot is that most of the eligible lands, and most of the controversy, is found in the latter two agencies.

While the Forest Service manages substantially more roadless acreage outside of designated wilderness than the BLM does, in recent years the debate over the future of the national forest roadless lands has centered around the Clinton Administration's roadless rule, rather than focusing on legislative designation. Moreover, these national forest lands may be somewhat less seriously threatened with development than BLM lands, because they tend to be more remote and in terrain less accessible to motorized vehicles. As a result, the BLM-long operating in the shadows of federal land management-has been thrust into the limelight of the battle over wilderness, with BLM lands in Utah at center stage.

The remainder of this paper focuses on the wilderness designation process for BLM lands. It follows up an examination of the subject I published nearly a quarter of a century ago. I concluded that paper with usual academic pomposity: "Success will be gauged by the amount and diversity of [BLM-managed] public lands which ultimately become part of the NWPS and the extent to which disruption of existing uses and rights is minimized. The results will not emerge for some time. ${ }^{17}$ My final observation was an understatement. In the two dozen years since those words were published, only Arizona (in 1984 and 1990) and California (in 1994) have seen significant BLM acreage designated as wilderness.

Overall, congressional designation of new wilderness has tended to come in pulses. The following graph shows the pace of designations:

\footnotetext{
${ }^{15}$ See 16 U.S.C. $\$ 1133(2000)$.

${ }^{16}$ See 43 U.S.C. $\S 1782$ (2000); see also John D. Leshy, Wilderness and Its Discontents: Wilderness Review Comes to Public Lands, 1981 ARIZ. ST. L.J. 361, 361-446 (providing a somewhat dated look at the issues raised by the BLM statutory wilderness framework) [hereinafter Leshy].

${ }^{17}$ Leshy, supra note 16, at 446.
} 


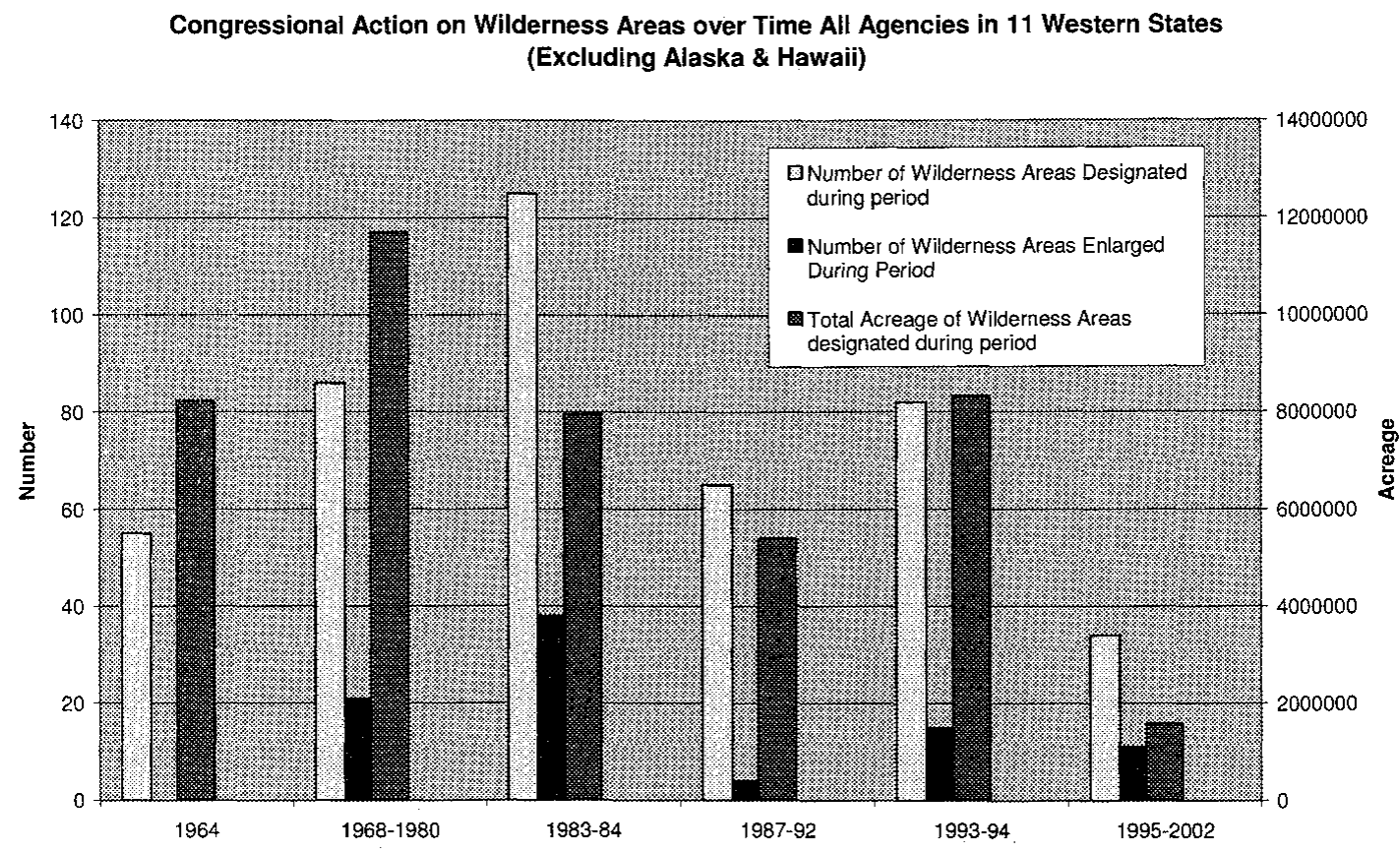

Source: Data complied from legislated acreage from the online public law database at Wilderness.net, a joint project of the Wilderness Institute at the University of Montana's College of Forestry and Conservation, the Arthur Carhart National Wilderness Training Center, and the Aldo Leopold Wilderness Research Institute, accessed online at

http://www. wilderness.net/index.cfm? fuse=NWPS\&sec=pubLawLib on Sept. 13-20, 2004

As this graph plainly shows, the pace of congressional designation has slowed significantly, as congressional enthusiasm for new wilderness designations has waned. Wilderness designation has also tended to become concentrated. In the first wave of post-Wilderness Act designations, 1968 through 1980, Congress designated wilderness areas in nine of the eleven western states (all but Nevada and Utah). In 1983 and 1984, the landmark 98th Congress designated areas in nine western states (all but Nevada and Colorado). Wilderness was designated in only five states, between 1987 and 1992, and in only three states in 1993 and 1994, and only Nevada has seen significant designations in the last decade.

Part of the explanation is ideological. In decades past, Congress had many champions of wilderness designation, including members from affected western states. In today's more conservative Congress-more hostile to regulation, more concerned about property rights, and more distracted by other issues-such champions are rare. Idaho has not enacted a wilderness bill since champion Frank Church left the Senate. Montana has not seen one since Lee Metcalf retired. More subtle factors also come into play. Experience with wilderness designation among members of Congress has declined with turnover. The major wilderness advances in the past were helped in part by a degree of knowledge, understanding, and trust among key legislators and staff which no longer exists and will take time to rebuild.

There are other reasons why BLM wilderness designation has not gone rapidly. One explanation is that the BLM started its wilderness review later than the other agencies and was not as well positioned to catch the congressional waves 
of wilderness designations before 1995. A second reason is the character and configuration of acreage under BLM stewardship. Compared to most other federal lands, BLM lands tend to be lower elevation, hotter, drier, downstream rather than in headwaters, and more accessible to recreational vehicle use. Moreover, they are sometimes incoherently configured, the inevitable result of the BLM's inheritance of the "lands no one wanted"-those left over after the statehood, railroad, homestead, and other land disposal programs had done their work. ${ }^{18}$ These awkward land ownerships can undermine wilderness eligibility, as well as greatly complicate conservation-minded land management. Although statistics on inholdings in BLM's wild lands are hard to come by, it is revealing that in the Four Corners states BLM's 3.2 million acres of "areas of critical environmental concern" (a designation category that overlaps somewhat with wilderness values) contain a staggering 550,000 acres of inholdings-more than one acre of inholding for every five acres of BLM land. ${ }^{19}$

A third reason for the slow pace of BLM wilderness designation involves the changing nature of the wilderness debate. Considering the federal land base as a whole, early wilderness bills made easier calls, in much the same way that easierto-address sources of pollution tended to be cleaned up first. "Rocks and ice" wilderness with few competing uses were the low-hanging fruit that Congress picked first. This was in part a response to the fact that timber and hardrock mining companies were the most important opponents of wilderness designation in the early days. The first areas designated tended to have little value for timber or mining companies, especially when the high cost of extraction from remote areas was taken into account. Isolation and rugged terrain were, of course, important reasons why these remote areas had never been roaded, privatized, logged, or mined. Even then, Congress would often oblige the industries by gerrymandering wilderness boundaries to exclude areas where timber or minerals were thought to be present.

Timber and mining, which tend to be concentrated in relatively few areas anyway, have declined in importance in western economies ${ }^{20}$ Concomitantly these interests have, over time, become somewhat less influential in wilderness designation. Today opponents of designation embrace a more diverse set of interests, including devotees of less primitive forms of recreation, off-road vehicle (ORV) users, and local governments that cater to them. Dramatic increases in ORV and mountain bike sales have made the recreation constituency a huge, unwieldy, and increasingly fractured one on the wilderness issue. Finally, although ranchers were somewhat assuaged by the Wilderness Act's protection for already

\footnotetext{
${ }^{18}$ See generally Leshy, supra note 16 , at 362-64.

19 See John-Paul Oliva et al., THe BuREau of Land Management's Conservation Mandate: AREAS OF CRITICAL ENVIRONMENTAL CONCERN IN ARIZONA, UTAH, COLORADO, AND NEW MEXICO (2004), at http://fguardians.org/pdf/acec-report.pdf (last visited Nov. 10, 2004).

${ }^{20}$ See RASKER ET AL., supra note 7, at 7-14.
} 
established grazing, ranchers remain skeptical if not downright opposed to new designations, partly on cultural grounds and partly because they perceive that federal land managers are tougher regulators of grazing inside wilderness than outside it.

***

The process of assembling and enacting bills designating wilderness eventually turns into a negotiation over identifying which areas to protect, drawing their boundaries, deciding how much acreage to "release" from wildernessconstraining management, and addressing whether to put in any special provisions regarding such things as livestock grazing and water rights. How such issues are resolved in individual bills may be regarded as a precedent for future wilderness bills, which can make their resolution more difficult.

Four issues are particular flash points in the contemporary discussion of BLM wilderness designation. One, oil and gas development, has long been an issue, but the Bush (II) Administration has pushed it to the forefront. The Clinton Administration leased many federal lands onshore-all told, it put more federal acreage under oil and gas lease (onshore and offshore) than the Reagan Administration did in its eight years. But the Clinton Administration also attempted, with considerable success, to avoid conflicts between leasing and wilderness values. By contrast, the Bush (II) Administration has targeted some places prized by wilderness advocates-Colorado's Roan Plateau, Montana's Rocky Mountain Front, New Mexico's Otero Mesa, and Wyoming's Red Desertfor greatly expanded oil and gas leasing. Some of the opposition this has provoked has come from unexpected quarters, including conservative ranchers and communities. A backlash has begun. For example, in a recent editorial captioned "Public Lands Under Attack," ${ }^{21}$ the Denver Post-hardly a house organ of the wilderness movement-accused the Administration of "trying to stop pristine lands in Colorado from getting the protection they deserve."

The second flash point concerns ORV use. The last couple of decades have seen a huge increase in these vehicles on federal lands, and their numbers, size, power, and capabilities are changing the backcountry. They flourish in a culture that celebrates vehicles and autonomy and freedom. Many federal land managers informally identify ORVs as their biggest management challenge, and the Forest Service has said that controlling ORV use is one of its highest priorities. Unauthorized or poorly-regulated ORV use can produce roads or other impacts that can disqualify areas from congressional designation. ${ }^{22}$ The Forest Service has documented thousands of miles of unauthorized roads on its lands, and BLM likely

\footnotetext{
${ }^{21}$ Editorial, Public Lands Under Attack, DENV. POST, Apr. 11, 2004, at E-6.

${ }^{22}$ See National OfF RoAd Vehicle COALITION, TAKEN FOR A RIDE: How OFF-ROAd VEHICLES DAMAGE THE NATION's WILDEST LANDS, at http:/www.wilderness.org/Library/Documents/upload/Taken-For-ARide-Complete-report.pdf (last visited Nov. 10, 2004).
} 
has at least as many. ${ }^{23} \mathrm{ORV}$ use is a major issue in designating wilderness in southern Utah, the Owyhee Canyonlands of southwestern Idaho, the Boulder White Clouds in central Idaho, and other potential wilderness. The U.S. Supreme Court's recent decision in Norton v. Southern Utah Wilderness Alliance ${ }^{24}$ has raised the stakes by making it more difficult for conservationists to litigate to force recalcitrant agencies to protect roadless areas from untrammeled ORV use.

The third flash point concerns rights-of-way. The primary problem here comes from potentially lax federal policies for acknowledging claims of rights-ofway over federal lands under a now-infamous old statute called RS 2477, which was enacted in 1866 and repealed in 1976 subject to valid existing rights. ${ }^{25}$ Here again the Bush (II) Administration has gone out of its way to pick a fight with wilderness advocates, using an obscure procedure-a provision in FLPMA that authorizes the Interior Secretary to issue so-called "disclaimers of interest" in federal lands ${ }^{26}$-and a secretly negotiated agreement with the state of Utah to open the door to widespread recognition of wilderness-disqualifying RS 2477 claims. $^{27}$

The fourth flash point arises from the awkward configuration of land holdings in some potential BLM wilderness. As isolation becomes increasingly prized in the face of encroaching civilization, more and more owners of in-holdings in potential wilderness areas are interested in developing their lands in ways inconsistent with wilderness. ${ }^{28}$ How such factors have complicated the politics of BLM wilderness designation is illustrated in such recent enactments as the Clark County, Nevada, legislation in 2002, ${ }^{29}$ and in the Steens Mountain legislation in Oregon two years earlier. ${ }^{30}$ These bills were much less omnibus than their counterparts in earlier eras. They designated a relatively small number of wilderness areas in a relatively small area of a single state. This suggests there are too many conflicts and not enough consensus support, given the current makeup of Congress and its key committees, to enact large packages of state- or region-wide wilderness bills. More important, each of these bills did many things besides just designating wilderness. They applied management prescriptions to some federal lands that were more protective than ordinary multiple use management, but not exactly wilderness. They also

\footnotetext{
${ }^{23}$ See generally Special Areas; Roadless Area Conservation, 66 Fed. Reg. 3,244 (Jan. 12, 2001) (discussing this issue in the preamble).

${ }^{24} 124$ S. Ct. 2373 (2004).

${ }^{25}$ See COGgINS ET AL., supra note 13, at 160-67.

${ }^{26}$ See 43 U.S.C. $\$ 1745$ (2000).

${ }^{27}$ See Stipulation and Joint Motion to Enter Order Approving Settlement and to Dismiss the Third Amended and Supplemental Complaint, Utah v. Norton, No. 2:90CV0870 B, (D. Utah April 11, 2003), at http://www.wilderness.org/Library/Documents/upload/Settlement-Between-Department-of-Interior-and-State-ofUtah.pdf (last visited Nov. 10, 2004).

${ }^{28}$ See generally Jim Carlton, Hot Properties: Private "Inholdings" in Federal Preserves, WaLL ST. J., July 28, 2004, at B1.

${ }^{29}$ Clark County Conservation of Public Land and Natural Resources Act of 2002, Pub. L. No. 107-282, 116 Stat. 1994 (codified as amended in scattered sections of 16 U.S.C.).

${ }^{30}$ See Steens Mountain Cooperative Management and Protection Act of 2000, 16 U.S.C. $\S \S 460 \mathrm{nnn}-1-122$ (2000).
} 
authorized purchases and land exchanges and addressed other management matters as well. This suggests that the foreseeable future might include fewer "standalone" wilderness bills which only designate wilderness. Instead, Congress might take the occasion to reconfigure land ownerships through approval of divestitures, acquisitions, or exchanges of federal land, and to protect some federal lands by means other than wilderness.

Package deals are, of course, common in the legislative process, because they can enable disparate interest groups to coalesce and form a strong consensus behind a package of measures in which each gets something each wants. Indeed, the original Wilderness Act was part of such a package deal. Wayne Aspinall, Chair of the House Committee with jurisdiction over wilderness designations (then called the House Interior Committee), a crusty curmudgeon from Colorado's West Slope, followed the theology that wilderness was to be tamed, not preserved. While he did not think kindly of the proposed Wilderness Act, he very much wanted Congress to create a blue-ribbon commission to prepare recommendations for overhauling the nation's public land laws. So in the end, a deal was struck-he got his commission and he let the Wilderness Act through his committee. ${ }^{31}$ It was a delicious irony, given Aspinall's attitude toward wilderness, that his brainchild (the Public Land Law Review Commission) in 1970 recommended that BLM lands undergo wilderness review. ${ }^{32}$ Congress eventually adopted that recommendation in section 603 of FLMPA $^{33}$ four years after Aspinall was denied renomination following redistricting. In the end, then, both parts of the Aspinall package deal proved to advance the cause of wilderness protection.

Including reconfigurations like land exchanges and employing non-wilderness designation labels (such as national conservation area) in wilderness legislation can grease the legislative process to obtain wilderness designations. At Steens Mountain in Oregon in 2000 and in the Southern Nevada legislation in 2002, designation of a "special management area" (Steens) and a national conservation area (Nevada) - along with a legislated land exchange at Steens and various public land adjustments and conveyances in southern Nevada-were important ingredients leading to designation of nearly two dozen wilderness areas.

The prospect of more package deals may pain some wilderness activists who distrust any protective label other than wilderness, and who do not want these other labels to be thought of as a substitute for wilderness designation, but rather only as an alternative, less desirable, and hopefully interim form of protection. Some may be reluctant to support the relinquishment of any federal land, whether by exchange or other disposition, as part of a wilderness deal. Controversies over

\footnotetext{
${ }^{31}$ See STEVEN C. SCHULTE, WAYNE ASPINALl AND THE SHAPING OF THE AMERICAN WEST 141-57, 23542 (2002); see also Leshy, supra note 16, at 368.

${ }^{32}$ Public Land Law Review Commission, ONE ThiRd of A NATION'S LaNd 198-99 (1970); see Leshy, supra note 16 , at $369-70$.

${ }^{33}$ See 43 U.S.C. § $1782(2000)$.
} 
these issues can divide pro-wilderness forces and undermine support for wilderness. If the current political climate demands that wilderness designation be part of a larger package that includes other adjustments in federal land holdings and land management, enacting new wilderness designations will likely become more difficult.

The issue of alternative designations is closely tied to another concern that has occasionally thwarted wilderness designation-_"release." If, as is usually the case, Congress decides to designate only some of the agency's eligible lands in the state or area it has under consideration as wilderness, what should the legislation say, if anything, about the future management of areas not designated? Ever since 1984, Congress has followed a "soft" release approach on national forest lands. This essentially says that roadless areas which Congress does not designate as wilderness are released for ordinary multiple use management, but the agency may reexamine whether to manage the area to preserve its wilderness values when it prepares its next land use plan for the area. "Soft" release is distinguished fromyou guessed it - the "hard" release favored by wilderness opponents. Hard release would permanently disqualify any area passed over by Congress from prowilderness agency management. ${ }^{34}$

On BLM lands, the matter is a little more complicated. In most of the few BLM bills to date, Congress has followed what looks like "hard" release, which generally provides that any wilderness study areas (WSAs) not designated as wilderness are no longer subject to the "non-impairment" management standard of FLPMA section $603 .{ }^{35}$ In fact, however, this was "soft" rather than "hard" release, because it left BLM with what it had long regarded as some discretion to create new wilderness study areas on these lands under FLPMA section 202, BLM's general land use planning authority. Congress also sometimes chose to continue formal WSA status, including its non-impairment management standard for certain areas. ${ }^{36}$ And sometimes Congress created new or expanded existing WSAs at the same time it was designating other areas as statutory wilderness. ${ }^{37}$

Here again, the Bush (II) Administration has taken a position hostile to wilderness protection and in the process thrown a monkey wrench in the release approach. In April 2003 it rejected a quarter-century of understanding-dating back to the Carter Administration-that BLM's ordinary FLPMA section 202 planning authority allowed it to designate and protect WSAs through its ordinary

\footnotetext{
${ }^{34}$ See CogGINS ET AL., supra note 13, at 1136-40.

${ }^{35}$ See, e.g., The Arizona Wilderness Act of 1984, Pub. L. No. 98-406 § 304, 98 Stat. 1485, 1494 (1984) (removing the Arizona Strip from wilderness study status); Arizona Desert Wilderness Act, Pub. L. No. 101-628 § 102, 104 Stat. 4469, 4474-75 (1990) (removing wilderness study designation from all Arizona land not previously designated wilderness); California Desert Protection Act of 1994, Pub. L. No. 103-433 §104, 108 Stat. 4471, 4481-82 (1994) (releasing land in the California Desert Conservation Area not previously designated as wilderness from wilderness study status); Clark County Conservation of Public Land and Natural Resources Act of 2002, Pub. L. No. 107-282 § 207, 116 Stat. 1994, 2004 (2002) (releasing various lands from wilderness study designation).

${ }^{36} 16$ U.S.C. $\S 460 \mathrm{nnn}-64$ (2000).

${ }^{37}$ See, e.g., Pub. L. No. 103-433 §§ 104-05, 108 Stat. 4471, 4481-83 (1994).
} 
land use planning process. ${ }^{38}$ Instead, the Bush (II) Administration denied BLM had authority to designate WSAs except through FLPMA section 603, an authority which had-rather conveniently from its anti-wilderness perspective-expired a dozen years earlier. The effect of this position-assuming it survives the court challenge wilderness advocates have brought ${ }^{39}$-strips BLM of any authority to create new WSAs through the land use planning process. The Bush (II) Administration has, in other words, converted "soft" release into "hard" release only.

Of course, Congress could change this outcome with new legislation. It could, for example, override BLM's refusal to designate new WSAs through reinstating "soft" release in any new BLM wilderness designation bills, or it could-as it sometimes does-directly designate areas outside WSAs as either wilderness or as new, statutory WSAs. But the current Congress may not be inclined to do so. This issue could become a serious point of contention in any new wilderness bills.

\section{$* * *$}

Finally, there is the question of what happens if the pace of wilderness designation continues to slow or jams up entirely. The Bush (II) Administration has shown a decided hostility toward wilderness, and House Resources Committee Chairman Richard Pombo has indicated he will not be enthusiastic about moving bills. Who suffers more from these stalemates, wilderness opponents or proponents? The answer, like much else in this review, is mixed.

Section 603 of FLPMA requires BLM to manage wilderness study areas designated pursuant to the authority of that section "so as not [to] impair the suitability of such areas for preservation as wilderness," until "Congress has determined otherwise." ${ }^{40}$ On these lands, then, wilderness proponents would seem

${ }^{38}$ See The Wilderness Society, No More Wilderness Policies, at http://www.wilderness.org/OurIssues/ BLM/Assault/NoMoreWild.cfm, (last visited Sept. 29, 2004). Section 202, BLM's generic land use planning authority, gives the Secretary a sweeping directive to "develop, maintain, and when appropriate, revise land use plans which provide by tracts or areas for the use of the public lands." These plans are supposed to rely on the "inventory of the public lands, their resources, and other values," called for by section 201, which inventory is supposed be prepared and maintained "on a continuing basis." Neither section 201 or 202 expressly calls for consideration of wilderness in this process. Section 603 calls for the Secretary, by October 1991, to "review" those roadless areas of public lands of five thousand acres or more which have been "identified" during the section 201 inventory "as having wilderness characteristics described in the Wilderness Act," and to report to the President his recommendation on whether such areas should be designated by Congress as wilderness. The President, in turn, is supposed to forward his recommendation to the Congress on the subject within two years of getting the Secretary's report. BLM has long administered section 202 as providing independent authority to designate WSAs in land use plans; for example, it has designated WSAs smaller than 5000 acres under this authority. (Section 603 could not be used for such small areas, because it applied only to roadless areas with wilderness areas over 5000 acres.) The Bush (II) Administration has belatedly concluded that section 603 provides the exclusive authority to create WSAs of any kind, as a carve-out from section 202's otherwise generic planning authority, and because that section called for the study process to be completed by 1991, it no longer exists.

${ }^{39}$ State of Utah v. Norton (S. Utah Wilderness Alliance, et al., appellants), appeal pending, No. 03-4147 (Tenth Circuit).

${ }^{40} 43$ U.S.C. $\$ 1782$ (2000). 
to have the upper hand, for only Congress can "release" them from protective status, and it is much easier to stop legislation than it is to enact it. But stalemate is not without risk here. For one thing, BLM may manage poorly and allow impairment by not adequately regulating off-road vehicle use. For another, Congress may grow so dissatisfied with gridlock that it eventually "sunsets" section 603's protection of WSAs. ${ }^{41}$

Then there are some millions of acres of BLM lands outside existing WSAs which have the potential to be designated wilderness. The wilderness values on these lands are primarily protected (if at all) through BLM's exercise of its management discretion. On these lands, stalemate would appear to operate in favor of wilderness opponents.

On all these candidate lands the attitude of the courts can be very important. In the past the lower federal courts have tended to demand strict compliance with the law, both procedurally and substantively, before allowing despoliation of potential wilderness areas. ${ }^{42}$ But recently the U.S. Supreme Court unanimously declined to take that approach, holding that the federal courts had no jurisdiction even to review, much less correct, agency inaction that allowed potential wilderness to be overrun with off-road vehicles. ${ }^{43}$ To the extent this attitude gets picked up by the lower courts, the path for wilderness advocates will get more difficult.

Wilderness advocates need to redouble efforts to change the political environment, to educate the public about the merits of wilderness designation, and to persuade elective officeholders to be more sympathetic to wilderness protection. But this will take time and is hardly certain of success. In the meantime, potential wilderness areas are subject to a variety of threats. Despite the complexities and the strong passions the issue evokes on all sides, there is room for some optimism. A hard look and a measure of pragmatism might uncover the makings of deals that are good for wilderness preservation. But such pragmatism can conflict with the idealism that fuels the movement. Furthermore, because development of potential wilderness is, generally speaking, irreversible, wilderness advocates are understandably cautious about making deals that do not protect all potential wilderness.

But the giants of the early wilderness protection movement understood that permanently protecting wilderness required some realism about the political process, and so they tempered their idealism enough to strike bargains and tried to make them as protective of wilderness as possible under the circumstances. BLM

\footnotetext{
${ }^{41}$ See the misleadingly named America's Wilderness Protection Act, H.R. 1153, 108th Cong. (2003).

${ }^{42}$ See CogGINS ET AL., supra note 13 at 1131-42; Parker v. United States, 448 F.2d 793, 795 (10th Cir. 1971), cert. denied, 405 U.S. 989 (1972); California v. Block, 690 F.2d 753 (9th Cir. 1982).

${ }^{43}$ See S.Utah Wilderness Alliance, 124 S. Ct. at 2373.
} 
wilderness advocates today face a similar prospect. On BLM land, it seems as true today as it was when I wrote in 1981 that the "results will not emerge for some [more] time." 
Heinonline -- 25 J. Land Resources \& Envtl. L. 142005 